Құрманалиева А.А., Әскенұлы Е.

Аінтанулық білім берудегі зайырлылық пен діндарлық принципі

Kurmanalieva A.D., Askenuly E.

\section{Secular and religious principle's in Religious Education}

Құрманалиева A.A., Әскенұлы Е.

Светский и религиозный принципы в религиоведческом образовании
Мақаяада білім берудегі діннің рөлі, мемлекет пен діннің арақатынасы, Аіндарлық, принципіне қатысты түсініктер, зайырлылық ұғымының анықтамалары тәрізді мәселелер зерттелген. Зайырлы мемлекеттегі дін феноменінің рөлі және осы саладағы шет мемлекеттердің тәжірибелері бұл еңбекте мұқият қарастырылды. Сонымен қатар дінтанулық білім беру ісіндегі негізгі басымдықтар мен проблемаларды шешу жолдары жан-жақты зерттелді.

Түйін сөздер: мемлекет, дін, зайырлылық, діндарлық, толлеранттылық, конфессия, білім беру.

In this article explores the definition of profane, concepts related with religiosity, the correlation of state and religion, the role of religion in the educational process. In this work clearly reviewed the role of religion in a secular state, and the experience of foreign countries in this approaches. In addition, the main advantages are deeply studied in religious education and ways to address issues regarding religion.

Key words: state, religion, profane, secularity, tolerance, confession, education.

В Аанной статье исследуется определение понятия светскости, связанное с религиозностью, соотношение государства и религии, роль религии в образовательном процессе. Четко рассмотрена роль религии в светском государстве и опыт зарубежных стран в Аанном направлении. Кроме этого, глубоко исследованы основные преимущества в религиоведческом образовании и способы решения проблемы относительно религиоведения.

Ключевые слова: государство, религия, светскость, религиозность, толерантность, конфессия, образование. 


\section{АІНТАНУАЫҚ БIАIM БЕРУАЕГI ЗАЙЫРАЫАЫК ПЕН АІНААРАЫҚ ПРИНЦИПІ}

\section{Кіріспе}

Бүгінгі таңда дінтанулық білім беру жүйесі қоғам өмірінің маңызды бөлігіне айналды. Білім берудің өзге де салалары тәрізді дінтануды да мазмұндық тұрғыдан байыту, жүйелеу қажет. Елімізде дінтанулық білім беру ісіне қатысты мәселелер әлі де толық шешімін тапқан жоқ. Дінтанулық білім берудегі аса өзекті мәселе қатарына діндарлық пен зайырлылық принципінің арақатынасын жатқыза аламыз. Біз өз зерттеуімізде осы пәнді оқыту үрдісі тек зайырлылық қағидаларына ғана жүгінгені жөн бе, әлде оқыту үрдісінде діндарлық принципіне де орын бар ма деген сауалдарға жауап іздедік. Демократия құндылықтары тереңдеп енген қазіргі кезеңде зайырлы сипаттағы мемлекеттік жүйелер көп таралған. Зайырлы мемлекеттерді мемлекет пен діннің ынтымақтастық дәрежесіне, діннің мемлекеттің құқықтық жүйесіне жүргізетін ықпалына қарап жіктеу үрдісі қалыптасқан. Зайырлы мемлекеттерді мынандай топтарға бөлуге болады: преференциалды, эквипотенциалды, контаминационды, идентификационды. Қазақстан Республикасы да зайырлы, унитарлы мемлекет қатарына жатады. ҚР Конституциясының 1 бөлімінің 1 тармағында: «Қазақстан Республикасы өзін демократиялық, зайырлы, құқықтық және әлеуметтік мемлекет ретінде орнықтырады, оның ең қымбат қазынасы - адам және адамның өмірі, құқықтары мен бостандықтары» - деп анық көрсетілген [1].

Зайырлы Қазақстанның қазіргі діни келбеті және зайырлы мемлекет ұғымының теориялық негіздері

2011-2012 жылдар аралығында Дін істері агенттігі (қазіргі Дін істері комитеті) тарапынан діни бірлестіктерді қайта тіркеу жүргізілген еді. Сол үрдістің нәтижесі бойынша Қазақстанда 17 конфессия өкілдерінен құралған 3088 діни бірлестік пен олардың филиалдары қалды. Мемлекеттік тіркеу мен қайта тіркеу еліміздегі діни бірлестіктер үлесін көрсетіп берді. Ол бойынша ислам діні - 72\%, православие - 9\%, католиктік - 3\%, протестанттық - 14\%, қалған діни конфессиялар 2\%-ды көрсетті [2].

Қазақ жерінде қазақтан өзге де ұлт пен ұлыстар тұрады. Ресми статистикаға сүйенсек, Қазақстанды 140 этнос пен 17 
конфессияның өкілдері мекендейді. Қазақстан жер жаһанға ұлтаралық және дінаралық татулықты сақтауымен танылып отыр. 2010 жылы 1-2 желтоқсанда елордамыз Астана қаласында ЕҚЫҰ саммитін өткізген сәтте де Қазақ елі басты ұранның бірі ретінде толлеранттылықты таңдағаны бекерден бекер емес. Қазақстанның ЕҚЫҰ-дағы төрағалығының ұраны латынның төрт «Т» әрпі болды: сенім (trust), дәстүр (tradition), транспаренттілік (transparency) және төзімділік (tolerance). Елімізде 2003 жылдан бері әр үш жыл сайын Әлемдік және дәстүрлі діндер съезі өтіп келеді. Діндер съезіне әлемдік діндермен қоса ұлттық діндердің көшбасшылары да қатысуда. Бұл жиында әлемді толғандырған аса маңызды мәселелерді түрлі дін өкілдері талқыға салып, ортақ бір шешім қабылдауға ұмтылуда. Теократиялық емес, зайырлы даму жолын таңдаған қазақ мемлекетінің қадамдары осындай реттілікпен түзілуде.

Қазақстан Республикасы Дін істері комитетінің Мәдениеттер мен діндердің халықаралық орталығының тапсырысы бойынша Қоғамдық ойпікірлерді зерттеу орталығы 2010-2011 жылдары зерттеу жүргізген еді. Зерттеу қорытындысы бойынша, халықтың 90\%-ы Қазақстандағы ең басты екі діни конфессияға, (яғни ислам $(54,7 \%)$ және православтық христиан $(36,2 \%))$ қатысы бар екенін айтқан. Қазақстан халқының бес пайызға жуығы өздерінде нақты бір дінде жоқ екенін айтca, сауалнамаға жауап берушілердің 2\% өздерін нағыз діншілдер деп есептейді екен. Өздерін діндармын деп санайтын, «өте діндармын» немесе «біршама діндармын» деп санайтындар 72,9\%-ға жетті. Көптеген зерттеу жүргізушілердің пікірлері бойынша, халықтың бір дінге жиналғанына қарамастан, діншілдік салттық немесе жасанды сипатта болады. Зерттеуге қатысушылардың 69\%-ы болашақта Қазақстанды зайырлы мемлекет ретінде көргілері келеді. Мемлекет құрылымында діннің қатысу идеясын ауылдықтардың 14,7\%-ы, қалалықтардың 18,4\%-ы қолдайды, ал діни мемлекетті жақтаушылар қала халқының 3,7\%-ын, ауыл халқының 5,3\%-ын құрайды. Зерттеу қорытындысы көрсетіп отырғандай, діншілдік деңгейі әртүрлі субъектілерге, оның ішінде мемлекеттік органдарды қоса алғанда сенушілер деңгейіне ықпал жасамайды. Діни ұйымдарға деген сенім, денсаулық сақтау мен білім беру ұйымдарына деген сенімнен кейінгі кезекте тұр. Еліміздегі әрбір оныншы адам дінге сенгіш бола бастаған, тағы да өздерін бұрын дінге сенбеушілерміз деп есептейтін 4,5\% адам Құдайға сене бастаған. Қазақстандық қоғамның діндарланып келе жатқаны осыдан анық байқалып тұр [3].

Зайырлы билік адамның рухани, ішкі әлеміне қатысы жоқ және оған қол сұқпайтын билік ретінде анықталды. Бірақ ол ешқашан да діндарлыққа қарсы және атеистік билікпен теңдестірілмеуі тиіс. Жалпы формасында зайырлы мемлекет шіркеудің мемлекеттен бөлінгенін, олардың қызмет ету аясында жіктелуін білдіреді. Әлемдік, ұлттық және ұсақ діндер негізінде әлемнің барлық мемлекеттерінде көптеген діни қауымдар қалыптасқан. Зайырлы мемлекетте ешбір дін мемлекеттік және міндетті дін ретінде бекітіле алмайды. Бұл ережеге сәйкес конституциялық норма ретінде бекітіледі. Мәселен, Испания корольдігінде «ешбір дін мемлекеттік деген сипатты ала алмайды» [4]. Егер діни ұйымдардың қызметі заңға қайшы болмаса мемлекет олардың қызметіне араласпайды. Зайырлы мемлекет пен діни ұйым арасындағы жіктелу өзара кедергі келтірмеу және заңдар немесе келісімдер арқылы реттеледі.

Саясат дін ықпалынан азат болуы үшін діни ұйымдар мен діндарлардың саяси қызметпен айналысуына шектеу қойылу қажет. Мұндай шектеу ең алдымен саяси партияларға материалды, ұйымдастырушылық және үгіт-насихаттық тұрғыдан қолдау көрсетуге тыйым тұрғысына қатысты болуы тиіс. Тұлғалық тұрғыдан сенушілердің ешбір саяси құқығына шектеу қоюға жол берілмейді, бірақ мұндай шектеулер кәсіби дін қызметкерлеріне қатысты қолданылуы мүмкін. Мұндай шектеулер кейбір мемлекеттердің конституцияларымен бекітілген. Мәселен Коста-Рика конституциясы дін қызметкерлерінің діни негізде немесе қандай да бір сенім арқылы саяси насихат жүргізуіне рұқсат бермейді, ал Мексика конституциясы бойынша діни культ қызметкерлері белсенді немесе пассивті сайлау құқығына ие емес және саяси мақсаттар үшін біріге алмайды [4].

А.Ш. Будагованың пікірі бойынша, «зайырлы мемлекет» дегеніміз - бұл барлығына міндетті ресми діні жоқ, діни қағидалар мен заңдылықтарды мемлекеттік органдарға ықпал етуші қайнаркөз деп санамайтын, шіркеу мемлекеттен және мектеп шіркеуден бөлінген, сондай-ақ барлық азаматтарға бірдей үкімі жүретін діни соттары жоқ мемлекеттің конституциялық сипаттамасы.

Ю.И.Стецовский зайырлы мемлекеттің мынандай сипаттарын бөліп көрсетеді:

1) ресми(мемлекеттік) діннің болмауы;

2) ешбір наным-сенім міндетті және ұстануға лайық деп мойындалмайды; 
3) діни канондар құқықтың қайнаркөзі болып саналмайды;

4) білім берудің мемлекеттік жүйесі мен тәрбие беру зайырлы сипатқа ие және дінге қатысты қандай да бір қатынасты құрылымдауды көздемейді;

5) ар-ұждан бостандығы, таңдау және діни қағидаларды тарату мәселелері - әр адамның рухани бостандығы мен жеке өмірінің көзі, оған мемлекеттің де, жеке тұлғалардың да араласуға құқығы жоқ [5].

Л. Юззелл (бүкіл дүние жүзінде ар-ұждан бостандығының қамтамасыз етілуін зерттейтін Кестон институтының бұрынғы директоры) зайырлылық мәселесі жөнінде былай дейді: «Мен мемлекеттік діннің болуын діни бостандықтың бұзылуы деп санамаймын: мемлекеттік дін Норвегияда, Ұлыбританияда бар. Егер Православие шіркеуі Ресейде мемлекеттік дін деп мойындалса, мен мұны адам құқықтарына қатысты заңсыздық деп есептемес едім» [6].

А.В. Малашенко зайырлы мемлекеттің үш сипатын белгілейді:

1) діни ұйымдардың мемлекеттен бөлінуі;

2) діннің саясаттан шеттетілуі;

3) «дін әр азаматтың жеке ісі болып табылады» [7].

И.А. Ильиннің мемлекет пен діннің арақатынасы жөнінде айтқан мына бір пікірі өте орынды: «Шіркеу мен мемлекет орнығуы, рухы және қадірі, мақсаты және әрекет етуі жағынан өзара жат. Өзіне шіркеудің күші мен қадір-қасиетін алғысы келген мемлекет көргенсіздігі пен руханиятқа деген қадірлемеушілігін байқатады. Өзіне мемлекеттің билігі мен қылышын алғысы келген шіркеу қадірін жоғалтады және өзінің бағытын өзгертеді. Шіркеу дінді тарату үшін де, еретик пен зұлымды жазалауға да, соғысу үшін де қылыш көтермеуі тиіс. Саяси іс-әрекеттер шіркеудің міндеті емес, саясат құралдары оның құралдарының мәні емес; саясат рангы шіркеудің рангы емес» [8].

Қазақстан Республикасының 2011 жылы 11 қазанда қабылданған «Діни қызмет және діни бірлестіктер» туралы заңында былай делінген: «Осы Заң Қазақстан Республикасының өзін демократиялық, зайырлы мемлекет ретінде орнықтыратынын, әркімнің ар-ождан бостандығы құқығын растайтынын, әркімнің діни нанымына қарамастан тең құқылы болуына кепілдік беретінін, халықтың мәдениетінің дамуы мен рухани өмірінде ханафи бағытындағы исламның және православтық христиандықтың тарихи рөлін танитынын, Қазақстан халқының діни мұрасымен үйлесетін басқа да діндерді құрметтейтінін, конфессияаралық келісімнің, діни тағаттылықтың және азаматтардың діни нанымдарын құрметтеудің маңыздылығын танитынын негізге алады» [9]. Бұдан мемлекетіміздің толықтай зайырлы сипатын анық аңғаруға болады. Зайырлы мемлекет дінсіз мемлекет емес, мұнда азаматтардың қалаған дінін ұстануға құқығы бар.

Білім беру ісіндегі діндарлық пен зайырлылық қағидаттары

Жалпы діндарлық - бұл діннің жекелеген тұлғаға немесе топқа ықпал етуі, сондай-ақ діни ұстанымдар мен қызметте болып жататын үрдістер мен тенденциялар топтамасы. Діни сана - белгілі бір индивидтің діни идеялар мен құндылықтарға, сондай-ақ белгілі бір дін мен діни топқа қатыстылығын білдіреді. Діни сана адам өмірінде әртүрлі кезеңде және әртүрлі жағдайларда қалыптасуы мүмкін. Бұл адамды діни қатынастар жүйесіне қосу арқылы және діни идеялар, құндылықтар, эмоционалды нормаларды қосу арқылы жүргізіледі. Көбінше діни сана отбасылық орта (діни отбасыда тәрбиелену) және қоршаған орта, діни жетекшілер мен уағызшылардың ықпалымен орнығады. Діни бірегейліктің қалыптасуына діннің қағидалары мен догматтары ғана емес, сонымен бірге түрлі мифтер, саяси қағидаттар және тұрмыстық көзқарастар да ықпал етеді. Мәселен, орыс халқының православтық санасы үшін Қасиетті Русь, «Мәскеу үшінші Рим» деген көзқарастар маңызды. «Мәдинада Мұхаммед, Түркістанда Қожа Ахмет, Маңғыстауда пір Бекет» деп жырлайтын қазақ халқы үшін де өзіндік құндылықтар жүйесі бар. О бастан-ақ Көк Тәңіріне сеніп, монотеистік сенім нышандарымен көзге түскен түркілер үшін ислам діні жат болмады. Міне осы түркілік кезеңнен бастап қазақ халқы мұсылман болып келеді. Базбіреулер қазақтың мұсылмандығына күмән келтіріп, әртүрлі сыңаржақ пікірлер айтып жатады. Бірақ әдеп-ғұрып, салт-дәстүр, фольклорьымыз мұсылмандық келбетімізді айғақтай түседі. Досқа адал, дұшпанға қатал ұлы қазақ халқы үшін төзімділік, қонақжайлық сияқты сипаттар тән. Міне осындай игі қасиеттеріміздің арқасында ғана жерімізге өзге этностар қоныстанып орныға алды. 1991 жылы 16 желтоқсанда тәуелсіздігін алып, 300 жылдық бодандық қамытынан босаған қазақ халқы елдік келбетін зайырлылық аясынан тапты. Мемлекеттік басқару, білім беру жүйесі, заң-жарғылардың барлығы дін ықпалынан азат болды. 
Зайырлы білім берудің жүйе құрушы сипаттары қатарына мыналар жатады:

- мемлекеттік мектептің ар-ұждан бостандығын бекіткен демократизмі мен гуманизмі, оқутәрбие үрдісінің дін мен шіркеуден тәуелсіздігі, окушының өз позициясын таңдау мүмкіндігі, білім беру үрдісінің объективті заңдылықтары мен субъектінің нақтылы мүмкіндіктерін өтейтін объективизмнің болуы;

- оқушылар бойында ғылыми білім мен танымның үздіксіз сипатын қалыптастыратын ғылыми рационалдылық;

- оқушының диалектикалық ойлауын дамытатын, қоғамдық өмір құбылыстары мен үрдістерін дұрыс түсінуге мүмкіндік беретін тарихилық көзқарастың қалыптасуы;

- білім берудің құқықтық реттеулерін, нормативті ережелер тәртібін және педагогикалық үрдістің барлық қатысушылары үшін саналы дисциплина болуын жолға қоятын құқықтық тәртіп пен заңдылық;

- толеранттылық, яғни ешбіріне басымдық берместен өзге альтернативті(діни) көзқарастар, идеялар, теорияларды мойындай білу;

- мектептегі білім берудің мемлекетпен, тұтас қоғаммен байланысын және ашықтығын қамтамасыз ететін бұқаралық сипаттың болуы.

Мемлекеттік білім берудегі зайырлылық қағидалары мынандай қызметтерді орындай білуі тиіс:

- оқушылар бойында ғылыми білім мен танымдық белсенділік, өзіндік көзқарастар, ұстанымдар, жеке позиция мен адамгершілікэтикалық идеалдар қалыптастыру;

- оқушылар бойында жалпыадамзаттық және жалпыұлттық құндылықтар, мемлекет пен қоғамның идеалдарына махаббат, төзімділік, бір-біріне құрмет көрсетуге жеткізетін гуманизм қалыптастыру;

- дінге деген қатынасына, көзқарасына қарамастан оқушылардың білім алуына және білім алушылардың өз-өзін қалыптастыруына жетелейтін тұлғалық қасиеттерін жетілдіруіне жәрдемдесетін басқарушылық сипат қалыптастыру;

- оқу-тәрбие үрдісінде білім алушыларды азаматтық, секулярлы құндылықтармен таныстыру, бірақ дін туралы білім беруді діни білім деп ұғуға болмайды.

Мектептегі білім беру кезінде ұстаз өзінің жеке сенімі мен дүниетанымына қарамастан барлық діндерге бейтараптылықпен қарауы тиіс, мұғалімнің бейтараптығы өскелең ұрпақты әртүрлі діни сенімдерге толеранттылықпен қарауға жетелейді.
Мемлекеттік мектептер халықтар мен ұлттар, мемлекет тарихындағы діннің рөлі мен орнын жоққа шығармауы тиіс. И.В. Понкин мемлекеттік және муниципалды білім берудің діни ұйымдар ықпалынсыз болуын бұрыс санап былай дейді: «Біз діни ұйымдарды азаматтық қоғамның өзге де институттарымен қатар ұлттық білім беру жүйесіне заң аясында ықпал етуге құқылы деп есептейміз» [10]. Бірақ ұстаздар қауымы шәкірттерге білім беру барысында мынандай педагогикалық шарттарды естен шығармауы тиіс:

- мектептің дінге деген қатынасы сенімге үйретуші емес, ақпараттық-танымдық сипатта болуы тиіс. Мемлекеттік білім беру бағдарламасы белгілі бір дінге, немесе атеизмге басымдық бермеуі тиіс, ал ұстаздар дінтанулық білім мен діни окуды меңгергені жөн;

- дінді зерттеуді әртүрлі білім беру пәндері (тарих, әдебиет, дінтанулық дәрістер және т.б.) контексті мен тәрбие беру үрдісіне (отбасы жөніндегі сұхбат, әртүрлі мерекелер өткізу) қосуға болады.

Келтірілген тұжырымдарымыз білім беру ісінде зайырлылық қағидаларының алар орнын көрсетіп беріп отыр. Мемлекет демократиялық, зайырлы даму үлгісінде болғандықтан оқу үрдісін де сол арнада жүргізеді. Мектеп мұғалімдері, орта арнаулы және ЖОО оқытушылары діндар болып, белгілі бір дін қағидаларын ұстануға құқылы. Бірақ аталған тұлғалар өз сенімдерін шәкірттеріне таңса, насихаттаса ол заңға қайшы.

Әрине мемлекет діннен бөлек болғанымен, қоғам мен дін өзара байланысты, екеуі де бір-бірінен ажырағысыз ұғымдар. Кез келген ұлттың өз бейнесінен, дүниетанымынан хабар беретін діні, тілі, ділі болады.Осылар көмегімен ұлттық сана, кескін-келбет қалыптасады. Біздің де сан мың жылғы менталитетімізді қалыптастыруға мол үлесін қосқан дініміз бар. Ол - ислам діні.

Дамыған өркениетті Батыс Еуропа елдерінің өзі ата діндеріне қандай да бір басымдылық беріп, ерекшелеп тұрады. Англия, Германия, Франция тәрізді мемлекеттер ата діндеріне белгілі бір қамқорлықтар көрсетеді. Мәселен, Норвегия Конституциясының 2-бабы Евангельдік-лютеран шіркеуін елдің мемлекеттік діні ретінде орнықтырады. Мемлекет шіркеудің барлық шығындарын өз мойнына алады және осы елдегі барлық балабақшалар мен мектептер заң бойынша «Мораль және Христиандық тәрбие» пәнінен сабақ өткізуі тиіс. Ал, Норвегияның заманауи түрдегі зайырлы мемлекет ретіндегі демократиялық жүйесі мен жетістіктеріне ешкімнің шек 
Құрманалиева А.Д., Әскенұлы Е.

келтірмесі анық [11]. Жалпы, өздерінің дәстүрлі діндеріне мемлекет өмірінде басымдық беретін мысалдарды әлемнің қай түкпіріндегі елдерден де көптеп кездестіруге болады. Біз де мұндай тәжірибенің қыр-сырын анықтап зерттеп, өз елімізде қолдана білуге тиіспіз. Бүгінгі заманда идеялар мен рухани бәсекелестік қарқынды жүруде. Бұл тартыста қазақ ұлты жеңіліске ұшырамағаны барлығымыз үшін де қажет. Сол себепті халқымыздың келешегі болатын болашақ ұрпақтың рухани саулығы және ұлттың амандығы үшін күресе білуге міндеттіміз. Осы себепті біз орта мектептер мен орта арнаулы оқу орындарында қазақтың әдеп-ғұрпы мен ата діні исламның негіздерімен таныстыратын пән міндетті түрде енгізілуі тиіс деп есептейміз. Көршілес Ресейде де «Православие мәдениетінің негіздері» деген пән енгізілгені белгілі. Солтүстіктегі көршіміз бұл курсты енгізудің қаншалықты маңызға ие екенін анық түсініп отыр. Жеткіншек ұрпақты ұлтты ұлт еткен қайнаркөздерден сусындату өте пайдалы іс болып табылады.

Әрине мұндай пәннің енгізілуі халықаралық ұйымдар мен отандық кейбір азаматтар тарапынан сынға алынуы мүмкін. Дәстүрлі емес діни бірлестіктердің жасаған құқық бұзушылығына көз жұма қарап, ал мемлекет тарапынан ол ағымдарға қандай да бір шара қолданылса «адам құқығы бұзылды, демократия жоқ» деп жаһанға жар салатын халықаралық ұйымдардың әрекетінің астары бізге түсінікті. Олар біздің діни саламызды бір жүйеге келтірген жаңа дін туралы заңымызды да сынға алған болатын. Өз азаматтарының қамын ойлаған Қазақстан түрлі халықаралық ұйымдардың бұл әрекетінен секем алмауы тиіс.

Жалпы алғанда, ҚР мектептерінде зайырлылық аясындағы «Зайырлылық және дінтану негіздері» пәнінің үлес салмағын көбейту мен ұлттық таным-түсінік қайнары исламды таныстыратын пәнді енгізу аса зор қажеттілік. Бұл қос пәннің екеуі де зайырлы тұрғыдан оқытылуы тиіс. Және аталған пәндердің екеуі де окушыларға анықтама-ақпараттар беруші рөлін атқарады. Ал бұл пәндерден дәріс беретін ұстаздар қауымы жоғарыда айтқанымыздай, жеке өмірінде діндар болғанымен, оқу орнында бейтараптылық принципін басшылыққа алғаны жөн. Бір айта кетерлігі 2016 жылғы жаңа оқу жылынан бастап, «Зайырлылық және дінтану негіздері» пәні ҚР мектептерінде міндетті сабақ ретінде жүргізілетін болады. Осы уақытқа дейін дінтанушы ғалымдар дінтану пәнінің мектептерде 34 сағаттық факультатив ретінде ғана жүргізіліп келе жатқанына наразы болып келген-ді. Мұндай қысқа уақыт ішінде оқушыларға дін жөнінде жеткілікті білім беру мүмкін емес екені айдан анық. ҚР азаматтарының діни сауаттылығын көтеру - бүгінгі күннің басты мәселесі болып табылады. Болашақта бұл пәннің мектептегі үлесі одан әрі кеңейтіле берілуі тиіс.

Дін - ол тазалық, дін - ол ізгілік. Әлемдегі діндердің барлығы адам баласын мейірімділікке, бір-біріне қамқор болуға шақырады. Дін - қоғам өмірін ретке келтіруге қабілетті. Бүгінгідей моральдық құлдыраулар көп орын алып жатқан кезеңде діннің игі функцияларын пайдалана білген жөн. «Дін мен мемлекеттің түйісер жері - елдің тұтастығы және қоғамның ауызбіршілігі мен тұрақтылығы. Сондықтан, ел дамуының бүгінгі кезеңінде екі тараптың өзара бірігіп әрекет ететін кеңістігін, оның құқықтық тетіктерін уақыт талабына сай айқындаудың және жетілдіріп отырудың маңызы зор. Бұл жерде мемлекет мынадай қағиданы басшылыққа алуы тиіс: ол қоғамдағы діни бірлестіктерді реттейтін өз шекарасының аумағын тарылтпауы керек және еліміздің негізін құрап отырған халықтың дәстүрлі дініне басымдық беруі қажет. Өйткені, қоғам мен дінді бір-бірінен бөлудің мүмкін емес екендігін ескерер болсақ, мемлекеттің діни салада белсенді түрде реттеуші болуы тиіс екендігі талас тудырмасы анық», - дейді Мәдениеттер мен діндердің халықаралық орталығының бөлім бастығы, саяси ғылымдар кандидаты М. Иманбаев [11].

«Батыс сарапшылары қоғамдағы діннің орны азайған сайын, адамдардың азуы, олардың бір-бірімен жауласуы сияқты жағымсыз жайттар белең алып, қылмыстың көбейетінін атап көрсетуде. Ислам елдерінде дін қоғамның осындай қатал тоңдарын жібітуші, қылмысты тежеуші фактор болып есептеледі» - дейді академик Ғ. Есім [12]. Расында да діннің рөлі әлсіреп бара жатқан Батыс Еуропа елдері мен АҚШ-та рухани азғындық белең алуда. Аталған мемлекеттерде біржынысты некеге тұрғандардың санының артуы мен олардың некесінің кейбір мемлекеттерде заңдастырылуы сорақылық болып табылады. Өкініштісі сол мұндай азғындықтардың салқыны біздің елімізге де тие бастады. Сол себепті ұрпақ тәрбиесі мәселесінде төл дініміз бен ататанымыздың потенциалын пайдалана білуге тиіспіз.

«Қай дінде болсын, біреудің ала жібін аттамау туралы ойлар жеткілікті. Сондықтан қоғамымызда діндердің маңызын арттыру өмірдің өзі ұсынып отырған шара екендігінде дау жоқ. Тіпті мемлекеттік қызметкерлердің рухани сана-сезімін арттыру жемқорлықтың алдын алуға көп көмек 
берер еді», - деп пікір білдіреді Мәдениеттер мен діндердің халықаралық орталығының директоры А. Абуов [13]. Мемлекет тарапынан жүргізілетін түрлі істерді жүзеге асыру мемлекеттік қызметшілерге тікелей байланысты екені айқын. Өз елін шынайы сүйетін патриот қызметшілері бар мемлекеттік жүйе биікке шығады. Ал қара басының қамын ғана ойлаған парақор, жалақор қызметшілер мемлекетті аяғынан шалуды ғана біледі. Осы себепті мемлекеттік интеллегенцияның дін қайнарынан сусындауы өте маңызды жайт. Осы орайда академик Ғ. Есімнің айтқан мына бір пікірі сөзімізді айғақтай түседі: «Біз бұдан былай қоғамға қызмет ететін мамандарды Құран Кәрімді меңгерген, зайырлы мемлекеттік қызметші дайындауды қолға алуымыз қажет іс. Сөздің қысқасы сауатты, білімді мұсылман интеллигенциясын қалыптастыруымыз қажет. Сонда мұсылман зиялылары деп кімдерді айтпақпыз? Олар имандылық пен әділет жолындағылар, олар ілім, ғылым игерген білікті мамандар. Мұндай азаматтарға коррупция және тағы басқа әділетсіздіктер жат болмақ. Болашақта бүгінгі зайырлы қоғамның зиялылары мен діни қызметкерлерінің біте қайнасып бірге өрбімей келе жатқан жолын тоғыстырып, түйістіретін болмақ. Бүгінгідей, ауыл-қалада емін-еркін өріп, әртүрлі діни ағымды насихаттап жүргендерге, мұсылмандықтан тайдыратын әрекеттерге тыйым жасай алмақ. Мұсылман зиялылары - жүрегінде иман, ісінде ізгілігі бар, діннен де, ғылымнан да хабары мол жандар болмақ〉 - дейді академик Ғ. Есім [14].

\section{Қорытынды}

Қорыта айтқанда дін мен қоғам өзара тығыс байланысты ажырамас жүйелер. Зайырлы қоғам дінсіз қоғам емес. Мұндай мемлекетте мансабына, қоғамдағы дәрежесіне қарамастан кез келген азамат дін ұстануға, діндар болуға құқығы бар. Тек ол азаматтардың дінді ұстануы заңда келтірілген нормаларға қайшы болмаса болғаны. Сонау Күлтегін жазбаларында тасқа қашалып жазылған «Мәңгілік ел» туралы қағиданы жаңғыртып, жаңа бетбұрыстар жасаған Қазақ елі үшін мемлекеттің баяндылығы қажет. Біз бұл жолда қазақты қазақ еткен қайнаркөздерді естен шығармай тиімді пайдаланғанымыз жөн. Сөзімнің соңын ҚР Мәдениет және ақпарат вице-министрі М.Әзілхановтың мына бір пікірімен аяқтағым келіп отыр: «Дін дегеніміз тек сенім жүйесі емес, ол өмір сүру мәнері, қарым-қатынас әдебі, моральдық нормалар жиынтығы, жақсы мен жаманды, адал мен арамды ажыратушы рухани қағидалар жүйесі. Сондықтан, дін мәселесі - рух мәселесі. Дінге руханият негізі ретінде қарап, оның жасампаз құндылықтарын, рухани әлеуетін басты назарға алған жөн. Діннің рухани әлеуетін мәңгілік идеяларға, зайырлылық идеяларына пайдалануға болады. Сол арқылы барлық жоғалтқанымызды түгендеп, мызғымас құндылықтар қалыптастыра аламыз» [15].

\section{Әдебиеттер}

1 ҚР Конституциясы //http://www.akorda.kz/kz/page/kazakstan-respublikasynyn-konstitutsiyasy_1339065134

2 Қайрат Лама Шәріп, Қазақстанның діни алаңы тазартылды //https://i-news.kz/news/2012/10/25/6691258 kairat_lama_ sharip_kazakstannyn_dini_ala.htm

3 Шлымова Г.Е. Дін мәселелері жөніндегі ғылыми зерттеу және талдау орталығының директоры, Қазақстан қоғамының құндылық бағдар жүйесіндегі діни құндылықтар // Ислам және өркениет газеті. - 10. 11. 2013. - № 13. - 12 б.

4 Конституции стран мира // uznal.org/constitution.php

5 Стецовский Ю.И. Право на свободу и личную неприкосновенность: Нормы и действительность. -М.: Дело, 2000. $718 \mathrm{c}$.

6 Юзелл Л. Я не считаю существование государственной религии нарушением религиозной свободы // Независимая газета. -6.10 .1991 . - № 19. -5 с.

7 Малашенко А.В. Исламское возрождение в современной России. -М.: Моск. Центр Карнеги, 1998. - 222c.

8 Ильин И.А. Одинокий художник. -М.: Исскуство, 1993. - 348 с.

9 Қазақстан Республикасының «Діни қызмет және діни бірлестіктер» туралы заңы // http://adilet.zan.kz/kaz/docs/ P1100000992

10 Понкин И.В. Правовые основы светскости государства и образования.- М.: Про-Пресс, 2003. - 416 с.

11 Иманбаев М. Зайырлы мемлекет және дәстүрлі дін: өзара әрекеттесу мәселелері // http://e-islam.kz/interview/ item/933-eislam

12 Нұрмұратов С. Мемлекеттік-конфессиялық қатынастар аясындағы зайырлылық мәселесі // Мемлекет және дін, 05.04.2013. - №4(27)

13 Әзілханов М. Жоғары руханият - зайырлы және діни құндылықтар негізі // «Егемен Қазақстан» газеті. - 18.07.2014. - № 55 
14 Есім Ғ. Нарық және ислам мәселелері // Жалын журналы. - №4№ - 2005.- 73 б.

15 Абуов А. Дамыған мемлекеттерде зайырлылықтың жүзеге асырылуы әртүрлі // Айқын газеті. - 04.03.2009. - №37.3 б.

16 Есім Ғ. Сана болмысы 10 кітап. - Алматы: «Қазақ университеті», 2007. - 309 б.

\section{References}

1 The Constitution of the Republic of Kazakhstan // http://www.akorda.kz/kz/page/kazakstan-respublikasynyn-konstitutsiyasy_1339065134

2 Kairat Lama Sharip, Qazaqstannyn dini alany tazartyldy //https://i-news.kz/news/2012/10/25/6691258 kairat_lama_sharip_ kazakstannyn_dini_ala.htm

3 Shlymova G.E. Din maseleleri zhonindegi gylymi zertteu zhane taldau ortalygynyn direktory, Qazaqstan kogamynynqundylyq bagdar zhuiesindegi dini qundylyqtar //Islam zhane orkeniet gazeti. - 10. 11. 2013. - № 13. - 12 b.

4 Konstitucii stran mira // uznal.org/constitution.php

5 Stecovski Y.I. Pravo na svobodu i lichnuyu neprikosnovennost: normy i dejstvitelnost. -M.: Delo, 2000. - 718 s.

6 Yuzell I. Ya ne schitayu sushhestvovanie gosudarstvennoi religii narusheniem religioznoi svobody // Nezavisimaya gazeta. -6.10.1991.- № 19. -5 s.

7 Malashenko A.B. Islamskoe vozrozhdenie v sovremennoi Rossii.- M.: Mosk. centr Karnegi, 1998. - 222s.

8 Ilin I.A. Odinokij hudozhnik. -M.: Isskustvo, 1993. - 348 s.

9 Qazaqstan respublikasynyn «Dini qyzmet zhane dini birlestikter» turaly zany // http://adilet.zan.kz/kaz/docs/p1100000992

10 Ponkin I.V. Pravovye osnovy svetskosti gosudarstva i obrazovaniya. -M.: Pro-press, 2003. - $416 \mathrm{~s}$.

11 Imanbaev M. Zaiyrly memleket zhane dasturli din: ozara arekettesu maseleleri // http://e-islam.kz/interview/item/933eislam

12 Nurmuratov S. Memlekettik-konfessiyalyq qatynastar ayasyndaqy zaiyrlylyq maselesi // Memleket zhane din. - 05.04.2013. - №4 (27) № 55

13 Azilxanov M. Zhogary ruyaniyat - zaiyrly zhane dini qundylyqtar negizi // «Egemen Qazaqstan» gazeti. - 18.07.2014. -

14 Esim G. Naryq zhane islam maseleleri // Zhalyn zhurnaly. - №4, 2005.- 73 b.

15 Abuov A. Damygan memleketterde zaiyrlylyqtyn zhuzege asyryluy arturli // Aiqyn gazeti. - 04.03.2009. - №37.- 3 b.

16 Esim G. Sana bolmysy 10 kitap. - Almaty: «Qazaq universiteti», 2007. - 309 b. 